\title{
Biological activities and chemical composition of Xanthoria lichens from Turkey
}

\author{
Muzaffer Mukemre ${ }^{\circledR 1}$, Gokhan Zengin ${ }^{(12}$, Rabia Sena Turker ${ }^{3,4}$, Ali Aslan ${ }^{(3,5}$, \\ Abdullah Dalar ${ }^{(D)}$,*
}
${ }^{1}$ Department of Plant and Animal Production, Yuksekova Vocational School, Hakkari University, Hakkari, 30100, Turkey
${ }^{2}$ Department of Biology, Faculty of Science, Selcuk University, Konya, Turkey
${ }^{3}$ Department of Pharmacology, Faculty of Pharmacy, Van Yuzuncu Yil University, Van, Turkey
${ }^{4}$ Department of Neuroscience, Graduate School of Health Sciences, Yeditepe University, Istanbul, Turkey
${ }^{5}$ Department of Biology, Faculty of Arts and Science, Kyrgyz-Turkish Manas University, Bishkek, Kyrgyzstan
${ }^{6}$ Department of Pharmaceutical Botany, Faculty of Pharmacy, Van Yuzuncu Yil University, Van, Turkey

\begin{abstract}
This study presents the biopharmaceutical potential and bioactive composition of Xanthoria lichens (X. candelaria, X. elegans, X. parietina) that wildly grown and traditionally utilized as medicine in North Eastern Anatolia, Turkey, which has specific microclimatic and ecological zones.

Chromatographic findings revealed significant levels of parietin compound (35 to 49 $\mathrm{mg} / \mathrm{g}$ extract), low levels of various fatty acids and a volatile compound; $\alpha$-terpinene in the extracts. The extracts exhibited pronounced antioxidant potential through reducing and scavenging mechanisms; FCR: 33-38 mg gallic acid equivalent, FRAP: 511-815 $\mu$ mol Fe ${ }^{2+}$, ORAC: $1032-1355 \mu$ mol Trolox equivalent per gram extract, respectively and DPPH: $\mathrm{IC}_{50}: 1.1-2.7$, ABTS: $\mathrm{IC}_{50}: 2-2.3$, CUPRAC: $\mathrm{IC}_{50}: 0.7-1.2$, phosphomolybdenum: $\mathrm{IC}_{50}$ : 2-2.9, metal chelation: $\mathrm{IC}_{50}: 1.3-2.3 \mathrm{mg}$ extract $/ \mathrm{ml}$, respectively. Concerning enzyme inhibitory activities, the extracts effectively suppressed the activity of acetylcholinesterase ( $\mathrm{IC}_{50}: 0.5-0.75 \mathrm{mg} / \mathrm{ml}$ ), butyrylcholinesterase ( $\left.\mathrm{IC}_{50}: 0.7-1.1 \mathrm{mg} / \mathrm{ml}\right)$, tyrosinase $\left(\mathrm{IC}_{50}: 0.6-0.7 \mathrm{mg} / \mathrm{ml}\right)$, amylase $\left(\mathrm{IC}_{50}: 1.7-2 \mathrm{mg} / \mathrm{ml}\right)$, glucosidase $\left(\mathrm{IC}_{50}: 0.6-3 \mathrm{mg} / \mathrm{ml}\right)$ and lipase $\left(\mathrm{IC}_{50}: 55-79\right.$ $\mu \mathrm{g} / \mathrm{ml}$ ) enzymes.

These findings showed that Xanthoria lichens are dominated by parietin as the major key compound and high-tolerated lichen taxa towards to different ecological and climatic conditions. These lichens might be promising sources of novel antioxidant and enzyme inhibitory activities such as Xanthoria candelaria as antioxidant and antilipase, Xanthoria elegans as anticholinesterase, and Xanthoria parietina as antiamylase and antiglucosidase.
\end{abstract}

\section{ARTICLE HISTORY}

Received: Sep. 12, 2021

Revised: Oct. 18, 2021

Accepted: Nov. 23, 2021

\section{KEYWORDS}

Xanthoria,

Bioactives,

Antioxidant,

Enzyme inhibition,

Natural agent.

\section{INTRODUCTION}

Lichens are stable, self-supporting, harmoniously, and continuous autotrophic complex symbiotic plantlike associations of photosynthetic green algae and/or cyanobacteria (photobiont) with at least one fungus (mycobiont). Such an association provides a unique

\footnotetext{
${ }^{*}$ CONTACT: Abdullah DALAR $\bigotimes$ dalar.abdullah@gmail.com
} Faculty of Pharmacy, Van Yuzuncu Yil University, Van, Turkey 
structure, which is utterly different from algae and fungi in terms of morphology, anatomy, physiology, and bioactivity.

These natural sources are able to grown in extreme habitats and ecological conditions such as arctic, alpine, and tropical rainforest zones and are significant sources of bioactive metabolites, which mainly composed of lichen acids and phenolic compounds (up to $10 \%$ dry weight of the thallus). These compounds absorb harmful UV-B radiation and minimize the harmful effects of environmental stresses such as high concentrations of salinity and protection against of the herbivores (Nybakken et al., 2004; Boustie \& Grube, 2005; Lina et al., 2015; Karthikadevi et al., 2011; Calcott et al., 2018).

Such accumulation of biologically active compounds in high quantities provides multiple biological and pharmacological effects to the lichens (Boustie \& Grube, 2005). Until now, a couple of drugs were developed from lichen sources such as Isla-Moos ${ }^{\circledR}$ and Broncholind ${ }^{\circledR}$ from Icelandic lichens (especially Cetraria islandica) and an antimycobacterial drug called clofazimine (Lamprene $\left.{ }^{\circledR}\right)$ from Irish lichen (Buellia canescens) (Reddy et al., 1999; Ingolfsdottir, 2002).

Lichens have been used by locals as food, fodder, perfume, spice, dyes and traditional medicines for a long time across the world. For instance, Cetraria islandica is used to treat lung, kidney, wound, bladder diseases and cancer; some species of Xanthoria are used in the treatment of jaundice; species of Lobaria and Parmelia are used to treat of lung and neural diseases (Chevallier 1996; Bown 2001; Hawksworth, 2003). In Anatolia, Xanthoria species are traditionally used for various ethno-lichenological purposes including medicinal utilization (antipyretics and jaundice). Also, they have been used as dyeing agents (personal communication, 2018).

Anthraquinones including parietin are among common bioactive compounds of lichens. Multiple scientific studies reported the chemical composition and some biological activities (with limitation on enzyme inhibitory potential) of Xanthoria lichens grown across the world and biopharmacological properties of their major compound "parietin" (Nybakken et al., 2004; Kumar et al., Basile et al., 2015; Cornejo et al., 2016; Ali \& Hameed, 2019). However, a very limited information is available in scientific literature on biologically active compounds and potential biological activities of Xanthoria lichens grown in Turkey. Environmental factors such as radiation, UV, and climatic variables are among the main modulators of chemical compounds accumulation in natural sources including plants, fungi, and lichens (Pirie et al., 2013). The North Eastern Anatolia Region of Turkey includes many microclimatic and ecological zones which enriched the development of diverse flora and fauna. Therefore, the chemical nature of Xanthoria lichens grown in this region may differ from those of originating from other parts of the world. Considering abovementioned aspects, this study aimed to research the biological activities (antioxidant and enzyme inhibition) of methanol-based extracts obtained from thalluses of Xanthoria lichens (Xanthoria Candelaria, Xanthoria elegans, and Xanthoria parietina) grown and traditionally utilized as food and medicine in Turkey and identify their chemical composition using proper chromatographic methodology.

\section{MATERIAL and METHODS}

\subsection{Lichen Materials}

Thallus samples of Xanthoria species (Figure 1) were harvested properly from wild as described below and transferred to the laboratory within 4 hours. Lichenological identities of lichen materials were done at Van Pharmaceutical Herbarium (VPH), Pharmacy Faculty, Van Yuzuncu Yil University, Van / Turkey and voucher specimens were deposited at VPH. The herbarium informations of the samples are detailed as follows: 
i. Xanthoria elegans (Link) Th.Fr.; Rize, Camlihemsin; Hayiki plateau, on Fagus orientalis, GPS coordinates 40 57'15'’N 4104'30'’E, 1400 m, Turkey, August 2018, Herbarium code: VPH-353; Collector code: AA825.

ii. Xanthoria parietina (Link) Th.Fr.; Rize, Camlihemsin; Hayiki plateau, on Fagus

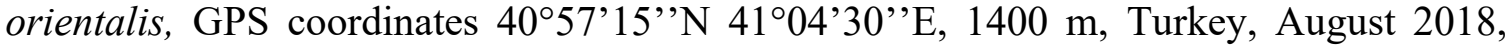
Herbarium code: VPH-354; Collector code: AA826.

iii. Xanthoria candelaria (L.) Th. Fr.; Artvin, Savsat; Merkezadam hill, siliceous rock, GPS coordinates $41^{\circ} 15^{\prime} \mathrm{N} 42^{\circ} 22^{\prime} \mathrm{E}, 1350 \mathrm{~m}$., Turkey, August 2018, Herbarium code: VPH-352; Collector code: AA827.

Figure 1. Xanthoria taxa from North Eastern Anatolia.

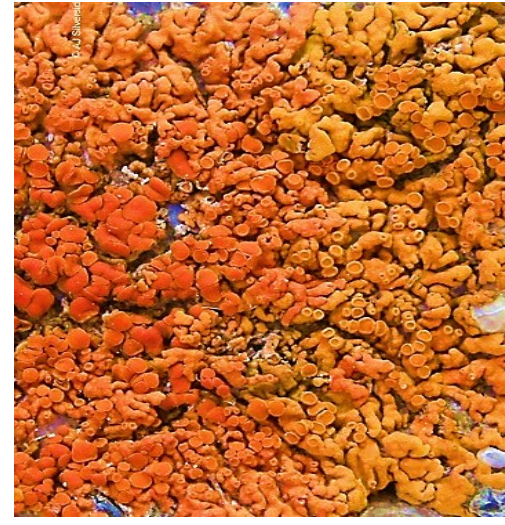

Xanthoria elegans

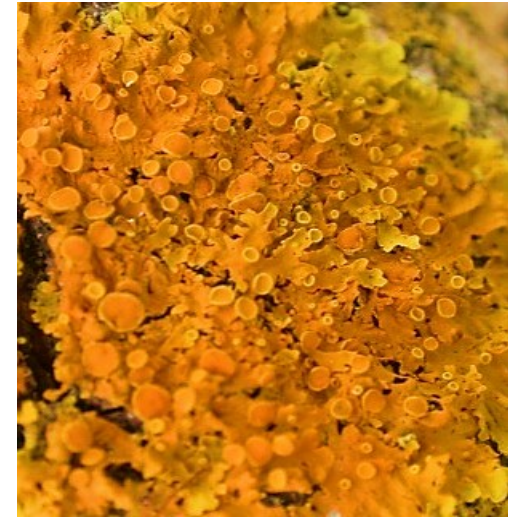

Xanthoria parietina

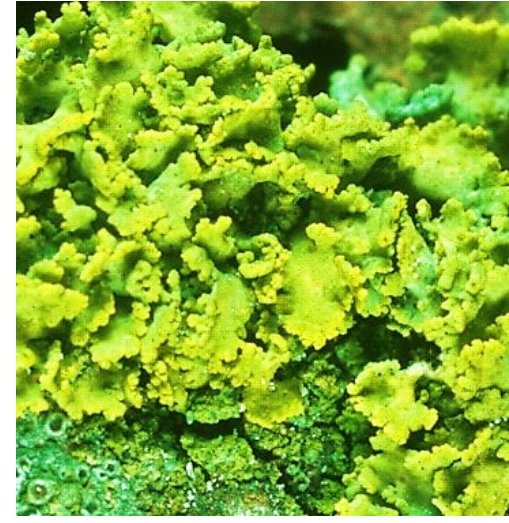

Xanthoria candelaria

\subsection{Chemicals}

Unless otherwise stated, all chemicals were obtained from Sigma-Aldrich, Inc. (St Louis, MO, USA) and were of analytical or HPLC grade.

\subsection{Preparation of Extracts}

Methanol has been reported as the most efficient and proper solvent for obtaining active ingredients from lichen matrix (Zambare \& Christopher, 2012) and hence, the extractions were prepared based on methanol solvent. The powder of lichen samples $(1 \mathrm{gr})$ was treated with a 10 -fold volume $(10 \mathrm{ml})$ of methanol $(80 \%$ methanol) and incubated for $2 \mathrm{~h}$ at room temperature $\left(22^{\circ} \mathrm{C}\right)$ with shaking. Then, homogenized mixture was filtered using vacuum filtration $(45 \mu \mathrm{m})$ with the supernatants collected and subsequently were evaporated using a rotary evaporator (Rotavapor R-205; Buchi, Switzerland). The derived concentrated fraction was freeze-dried using a lyophilizator (Alpha1-2 LDplus, Christ, Germany) under a vacuum at $-51{ }^{\circ} \mathrm{C}$ to obtain fine lyophilized methanol powder.

\subsection{Folin-Ciocalteu Reducing Assay}

Folin-Ciocalteu reducing capacities of the extracts were measured as described previously by Ainsworth \& Gillespie (2007) and were expressed as mg gallic acid equivalents per gram of dry weight of the lyophilized extracts, based on gallic acid standard curve and against a blank control. The analyses were conducted in triplicate.

\subsection{Antioxidant Capacity}

Ferric reducing antioxidant power (namely total reducing; FRAP) assay was conducted according to (Benzie \& Strain, 1996) and total reducing capacities of the extracts were expressed as $\mu \mathrm{mol}$ of iron $\left(\mathrm{Fe}^{2+}\right)$ per gram of dry weight of lyophilized extracts based on an iron sulphate standard $\left(\mathrm{Fe}_{2} \mathrm{SO}_{4}\right)$ curve against a blank control. Oxygen radical scavenging 
(ORAC) capacities of the extracts were measured as described previously by Dalar \& Konczak (2013) and the results were expressed as $\mu$ mol Trolox equivalent per gram of dry weight of lyophilized extract based on a Trolox standard curve.

The total antioxidant (TAC; phosphomolybdenum method), DPPH radical scavenging, ABTS radical cation scavenging, the cupric ion reducing (CUPRAC), and metal chelating activities of the extracts were determined as described previously described by Uysal et al. (2017) and the results were expressed as $\mathrm{IC}_{50}$-half maximal inhibitory concentration (mg extract $/ \mathrm{ml})$.

\subsection{Enzyme Inhibitory Activities}

Cholinesterase (ChE), $\alpha$-amylase, $\alpha$-glucosidase, and tyrosinase inhibitory activities of the extracts were determined according to Zengin (2016) and expressed as $\mathrm{IC}_{50}$-half maximal inhibitory concentration $(\mathrm{mg}$ extract $/ \mathrm{ml})$. The pancreatic lipase activity was assayed as described previously (Dalar and Konczak, 2013) using 4-methylumbelliferyl oleate ( $0.1 \mathrm{mmol})$ as a substrate and the results were expressed as $\mathrm{IC}_{50}$-half maximal inhibitory concentration $(\mathrm{mg}$ extract $/ \mathrm{ml}$ ). All enzyme inhibitory analyses were conducted in triplicate.

\subsection{HPLC-MS/MS Analysis}

Identification and quantification of phenolic compounds by high performance liquid chromatography-diode array detector (HPLC-DAD) and liquid chromatography-photo-diode array-mass spectrometry (LC-PDA-MS/MS) (Thermo Fisher Scientific, Waltham, MA, USA) analysis were conducted as described previously (Dalar \& Konczak, 2013). The composition of phenolic compounds was characterized based on their UV spectrum, retention time, cochromatography with commercial standards, when available, and MS/MS fragmentation patterns. MS experiments in the full scan (parent and product-specific) and the selected reaction monitoring (SRM) mode were conducted. All analyses were conducted in triplicate.

\subsection{GC-MS Analysis}

Volatile compounds and fatty acids were analyzed by gas chromatography mass spectrometry (GC/MS) (3800 Varian GC, Agilent Technologies, Istanbul, Turkey) using a head space solid phase micro extraction and identified by the fragment ions and relative retention indices of their peaks with those of the MS library standards as described previously (Uzun et al., 2017). All analyses were conducted in triplicate.

\subsection{Data Analysis}

The mean values were calculated based on at least three determinations $(n=3)$. One-way ANOVA followed by the Bonferroni post-hoc test was performed to assess differences between the samples at the level of $\mathrm{p}<0.05$ through Graphpad Prism 5 (Graphpad Software, CA, USA).

\section{RESULTS and DISCUSSION}

\subsection{Total Phenolic Contents and Antioxidant Capacities}

The pathological and detrimental environmental conditions disrupt the antioxidant balance in the cells and tissues and thus elevated the amount of the reactive oxygen species or other free radicals and finally resulted in oxidative stress which was associated with many metabolic and neurological diseases (Moldovan, 2004; Prior, 2015).

Table 1 presents antioxidant activities of the samples through various assays which have different and complementary mechanisms. A pattern of $X$. candelaria $>X$. parietina $>X$. elegans was observed in total phenolic content and all assays of antioxidant measurements. Solely, $X$. elegans exhibited superior metal chelation activities than those of $X$. candelaria and $X$. parietina (Table 1). Although the lichen extracts were found as effective antioxidant sources 
that capable both of single electron and hydrogen atom transfer, and as well as metal binding mechanisms, they showed weaker antioxidant activities compared to synthetic antioxidant agents such as ascorbic acid, butylated hydroxyanisole, Trolox, and ethylenediamine tetraacetic acid which were used as positive controls in the present study (Table 1).

Kumar et al. (2014) investigated antioxidant activities of several lichen samples grown high altitudes of cold deserts and reported Xanthoria elegans as active antioxidant source among 14 lichens evaluated. The authors also reported total phenolics content of Xanthoria elegans (19.7 $\mathrm{mg}$ gallic acid equivalent/g extract) which is approximately 0.5 -fold that of our finding. This difference can be explained by the varieties in climatic and environmental factors of TransHimalayan Cold Desert (harsh climatic conditions) and Northern Eastern Anatolia (warm and rainy climatic conditions). The positive correlations between total phenolic contents and antioxidant determination (a range of $r^{2}=0.8-0.98$ ) suggest phenolic compounds as the potential major contributor of the antioxidant activities (except metal chelation activities) of the extracts, which was in agreement with previous antioxidant reports of lichen samples (Manojlovic et al., 2012; Atalay et al., 2011; Fernandez-Moriano et al., 2016). Based on these findings, it can be suggested that Xanthoria lichens might be promising sources of novel antioxidant agents particularly as oxygen radical scavengers. 
Table 1. Total phenolic contents and antioxidant activities of Xanthoria extracts.

\begin{tabular}{|c|c|c|c|c|c|c|c|}
\hline \multirow[b]{2}{*}{ Antioxidant activity } & \multicolumn{3}{|c|}{ Xanthoria Lichens } & \multicolumn{4}{|c|}{ Positive control (Synthetic antioxidants) } \\
\hline & $\begin{array}{l}\text { Xanthoria } \\
\text { elegans }\end{array}$ & $\begin{array}{l}\text { Xanthoria } \\
\text { parietina }\end{array}$ & $\begin{array}{l}\text { Xanthoria } \\
\text { candelaria }\end{array}$ & $\begin{array}{l}\text { Ascorbic } \\
\text { acid }\end{array}$ & $\begin{array}{l}\text { Butylated } \\
\text { hydroxyanisole }\end{array}$ & Trolox & $\begin{array}{l}\text { Ethylenediamine } \\
\text { tetraacetic acid }\end{array}$ \\
\hline Folin-Ciocalteu reducing (Total phenolics) ${ }^{1}$ & $34 \pm 2 d$ & $39 \pm 1 c$ & $47 \pm 2 b$ & - & - & - & - \\
\hline Ferric reducing antioxidant power ${ }^{2}$ & $511 \pm 14 d$ & $591 \pm 35 c$ & $815 \pm 17 b$ & $5138 \pm 19 \mathrm{a}$ & - & - & - \\
\hline Oxygen radical absorbance capacity ${ }^{3}$ & $1033 \pm 67 d$ & $1263 \pm 38 c$ & $1355 \pm 26 b$ & - & $6092 \pm 82 \mathrm{a}$ & - & - \\
\hline DPPH radical scavenging activity ${ }^{4}$ & $>3 d$ & $2.7 \pm 0.6 \mathrm{c}$ & $1.1 \pm 0.1 b$ & - & - & $0.06 \pm 0.01 \mathrm{a}$ & - \\
\hline ABTS radical scavenging activity ${ }^{4}$ & $>3 d$ & $2.3 \pm 0.1 \mathrm{c}$ & $2 \pm 0.1 \mathrm{~b}$ & - & - & $0.18 \pm 0.02 \mathrm{a}$ & - \\
\hline Cupric ion reducing antioxidant capacity ${ }^{4}$ & $1.2 \pm 0.0 \mathrm{c}$ & $1.1 \pm 0.0 \mathrm{c}$ & $0.7 \pm 0.0 \mathrm{~b}$ & - & - & $0.11 \pm 0.01 \mathrm{a}$ & - \\
\hline $\begin{array}{l}\text { Phosphomolybdenum total antioxidant } \\
\text { capacity }{ }^{4}\end{array}$ & $>3 d$ & $2.9 \pm 0.4 \mathrm{c}$ & $2 \pm 0.2 \mathrm{~b}$ & - & - & $0.55 \pm 0.1 \mathrm{a}$ & - \\
\hline Metal chelation activity ${ }^{4}$ & $1.3 \pm 0.0 \mathrm{~b}$ & $2.3 \pm 0.1 \mathrm{~d}$ & $1.8 \pm 0.2 \mathrm{c}$ & - & - & - & $0.03 \pm 0.0 \mathrm{a}$ \\
\hline
\end{tabular}

Means with different letters in the same row were significantly different at the level $(p<0.05), \mathrm{n}=3$.

${ }^{1} \mathrm{mg}$ Gallic acid Equivalent/g extract,

${ }^{2} \mu \mathrm{mol} \mathrm{Fe}{ }^{2+} / \mathrm{g}$ extract,

${ }^{3} \mu$ mol Trolox Equivalent/g extract,

${ }^{4} \mathrm{IC}_{50}$-half maximal inhibitory concentration $(\mathrm{mg}$ extract $/ \mathrm{ml})$. 


\subsection{Enzyme Inhibitory Activities}

Enzyme inhibitory strategy such as utilization of acarbose, orlistat, voglibose, captopril etc. is commonly applied towards several metabolic diseases globally. However, their unwanted effects (diarrhea, abdominal pain, gas, etc.) (Copeland, 2000; Gonçalves \& Romano, 2017), induces exploring novel safe and effective enzyme inhibitors from natural sources to minimize abovementioned side effects (Dalar \& Konczak, 2013; Zengin, 2016; Uysal et al., 2017; Uzun et al., 2017).

Lichens are potent novel candidates of enzyme inhibitors due to high levels of their bioactive components. For instance, effective antidiabetic potential of lichens has been revealed through the inhibitory activity mechanism of carbohydrate hydrolyzing enzymes ( $\alpha$ - amylase and $\alpha$ glucosidase) and their hypoglycemic action has been linked to the presence of high amount of phenolic compounds (Raj et al., 2014; Shivanna et al., 2015; Valadbeigi \& Shaddel, 2016; Zambare \& Christopher, 2012; Kekuda et al., 2019). Moreover, novel effective cholinesterase inhibitor agents such as biruloquinone, lobaric acid, and perlatolic acid were recently isolated from lichens (Kekuda et al., 2019), which indicate their effective enzyme suppressive abilities.

Table 2. Enzyme inhibitory activities of Xanthoria extracts.

\begin{tabular}{|c|c|c|c|c|c|}
\hline & & & $\begin{array}{l}\text { Xanthoria } \\
\text { elegans }\end{array}$ & $\begin{array}{l}\text { Xanthoria } \\
\text { parietina }\end{array}$ & $\begin{array}{l}\text { Xanthoria } \\
\text { candelaria }\end{array}$ \\
\hline \multirow{12}{*}{ 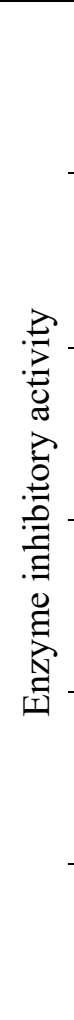 } & \multirow[b]{2}{*}{ Acetylcholinesterase } & $\mathrm{IC}_{50}(\mathrm{mg} / \mathrm{ml})$ & $0.5 \pm 0.0 \mathrm{a}$ & $0.8 \pm 0.0 \mathrm{c}$ & $0.6 \pm 0.0 \mathrm{~b}$ \\
\hline & & $\begin{array}{l}\text { Galanthamine Equivalent } \\
(\mathrm{mg} / \mathrm{g} \text { extract })^{*}\end{array}$ & $5.5 \pm 0.1 \mathrm{a}$ & $3.9 \pm 0.1 \mathrm{c}$ & $4.5 \pm 0.1 b$ \\
\hline & \multirow[b]{2}{*}{ Butyrylcholinesterase } & $\mathrm{IC}_{50}(\mathrm{mg} / \mathrm{ml})$ & $0.7 \pm 0.0 \mathrm{a}$ & $1.1 \pm 0.0 \mathrm{c}$ & $0.8 \pm 0.0 \mathrm{~b}$ \\
\hline & & $\begin{array}{l}\text { Galanthamine Equivalent } \\
(\mathrm{mg} / \mathrm{g} \text { extract })^{*}\end{array}$ & $4.7 \pm 0.1 \mathrm{a}$ & $3.1 \pm 0.0 \mathrm{c}$ & $4 \pm 0.2 b$ \\
\hline & \multirow[b]{2}{*}{ Tyrosinase } & $\mathrm{IC}_{50}(\mathrm{mg} / \mathrm{ml})$ & $0.7 \pm 0.0 \mathrm{~b}$ & $0.6 \pm 0.0 \mathrm{a}$ & $0.6 \pm 0.1 \mathrm{a}$ \\
\hline & & $\begin{array}{l}\text { Kojic acid Equivalent (mg/g } \\
\text { extract) }{ }^{*}\end{array}$ & $127 \pm 1 b$ & $134 \pm 0.6 \mathrm{a}$ & $132 \pm 0.2 \mathrm{a}$ \\
\hline & \multirow[b]{2}{*}{ Alpha-Amylase } & $\mathrm{IC}_{50}(\mathrm{mg} / \mathrm{ml})$ & $2.1 \pm 0.1 \mathrm{~b}$ & $1.7 \pm 0.1 \mathrm{a}$ & $2.0 \pm 0.1 \mathrm{~b}$ \\
\hline & & $\begin{array}{l}\text { Acarbose Equivalent } \\
(\mathrm{mmol} / \mathrm{g} \text { extract })^{*}\end{array}$ & $0.5 \pm 0.0 \mathrm{~b}$ & $0.6 \pm 0.0 \mathrm{a}$ & $0.5 \pm 0.0 \mathrm{~b}$ \\
\hline & \multirow[b]{2}{*}{ Alpha-glucosidase } & $\mathrm{IC}_{50}(\mathrm{mg} / \mathrm{ml})$ & $>3 b$ & $0.6 \pm 0.0 \mathrm{a}$ & NA \\
\hline & & $\begin{array}{l}\text { Acarbose Equivalent } \\
(\mathrm{mmol} / \mathrm{g} \text { extract })^{*}\end{array}$ & $0.7 \pm 0.1 \mathrm{~b}$ & $11 \pm 0.1 \mathrm{a}$ & NA \\
\hline & \multirow[b]{2}{*}{ Pancreatic Lipase } & $\mathrm{IC}_{50}(\mu \mathrm{g} / \mathrm{ml})$ & $79 \pm 5 \mathrm{c}$ & $68 \pm 5 b$ & $55 \pm 3 a$ \\
\hline & & $\begin{array}{l}\text { Orlistat Equivalent }(\mu \mathrm{mol} / \mathrm{g} \\
\text { extract })^{*}\end{array}$ & $38 \pm 1 \mathrm{c}$ & $41 \pm 1 b$ & $69 \pm 2 a$ \\
\hline
\end{tabular}

Means with different letters in the same row were significantly different at the level $(p<0.05), \mathrm{n}=3$. NA: not active (no any inhibition was observed).

*The equivalent of commercial standards calculated based on a standard curve and against control.

X.elegans was detected as the most effective inhibitor of $\mathrm{AChE}, \mathrm{BChE}$, and tyrosinase followed by $X$. candelaria and $X$. parietina. Concerning diabetes related enzymes; all extracts showed low inhibitory activity $\left(\mathrm{IC}_{50} \geq 1.7 \mathrm{mg}\right.$ extract $/ \mathrm{ml}$ ) in $\alpha$-amylase and $\alpha$-glucosidase $\left(\mathrm{IC}_{50}\right.$ $\geq 3 \mathrm{mg}$ extract $/ \mathrm{ml}$; with the exception of $X$. parietina $\left(\mathrm{IC}_{50}=0.5 \mathrm{mg}\right.$ extract $\left./ \mathrm{ml}\right)$ ). With regards to pancreatic lipase inhibition, all extracts exhibited pronounced levels (IC50 $\geq 55 \mu \mathrm{g}$ extract $/ \mathrm{ml}$ ) (Table 2). These findings revealed that Xanthoria lichens might be among new 
promotive sources of enzyme inhibitors; specifically, Xanthoria candelaria as antilipase, Xanthoria elegans as anticholinesterase, and Xanthoria parietina as antiamylase and antiglucosidase.

\subsection{Chemical Profiles}

Chemical profiling of lichen samples was shown in Table 3 and Figures 2-3. HPLC-MS/MS data showed that the dominant compound of the extracts gave a negatively charged molecular ion (M1]') at m/z 283 and MS/MS fragment was $283 \mathrm{~m} / \mathrm{z}$. Based on neutral loss, fragmentation pattern, molecular weight, absorbance spectrum and co-chromatogram analyses, it was tentatively identified as parietin. This compound was found in all Xanthoria species and contributed $90 \% \geq$ of the phenolic compositions of the extracts. Other phenolic compounds were detected in low amounts correspond to their trace levels individually (contribution of $\leq$ $2 \%$ of total phenolics) (Figure 1). These findings were in coherence with chemical composition of Xanthoria species reported previously (Ali \& Hameed, 2019), which showed that Xanthoria lichens were high-tolerated lichen taxa towards to different ecological and climatic conditions.

Figure 2. Representative HPLC profile of Xanthoria taxa (Xanthoria candelaria).

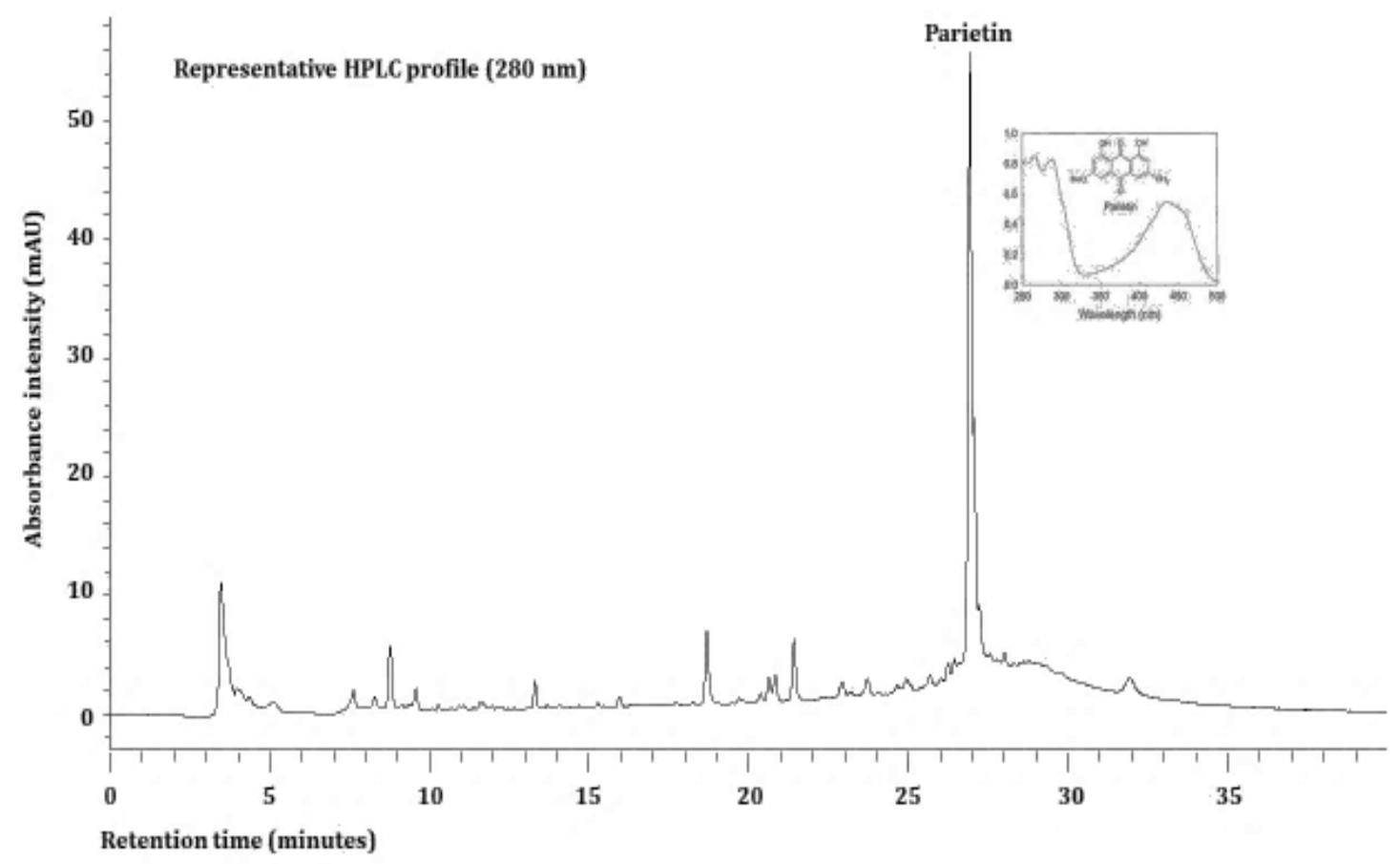

Parietin is an anthraquinone that responsible from the orange yellowish color of Xanthoria species, which is able to absorb blue light (Basile et al., 2015). It was reported that parietin was a biologically active compound that exhibit effective antibacterial, anticancer, antiproliferative, and antifungal activities (Lopez-Tobar et al., 2016), and pronounced antioxidant activity (Gundogdu et al., 2019).

With regards to GC-MS analyses, five fatty acids (palmitic, stearic, oleic, linoleic and $\alpha$ linolenic acid) and a volatile compound (alpha-terpinene) were identified in the extracts (Table 3 and Figure 3). The presence of alpha-terpinene in Xanthoria lichens has not been reported previously in our knowledge. Torres et al. (2003) investigated fatty acid composition of Xanthoria parietina and reported the presence of palmitic, stearic and very long chain fatty acids, which was slightly similar to our findings. Piervittori et al. (1994) researched the fatty acid variations of Xanthoria parietina and reported a similar composition to our findings. The 
authors also emphasized a general trend of decreasing fatty acid unsaturation with elevation. At an elevation of $1300 \mathrm{~m}$, the authors found a minor increase in palmitic acid, but a drastical decrease in linoleic acid. This finding showed that there is a negative correlation between the elevation and accumulation of linoleic acid in lichen tissues. Although a scalar quantity in fatty acid composition of the extracts, their levels were at low quantities and it can be speculated that they have a secondary contribution to the biological activities of Xanthoria lichens.

Figure 3. Representative GC-MS profile of Xanthoria taxa (Xanthoria candelaria).

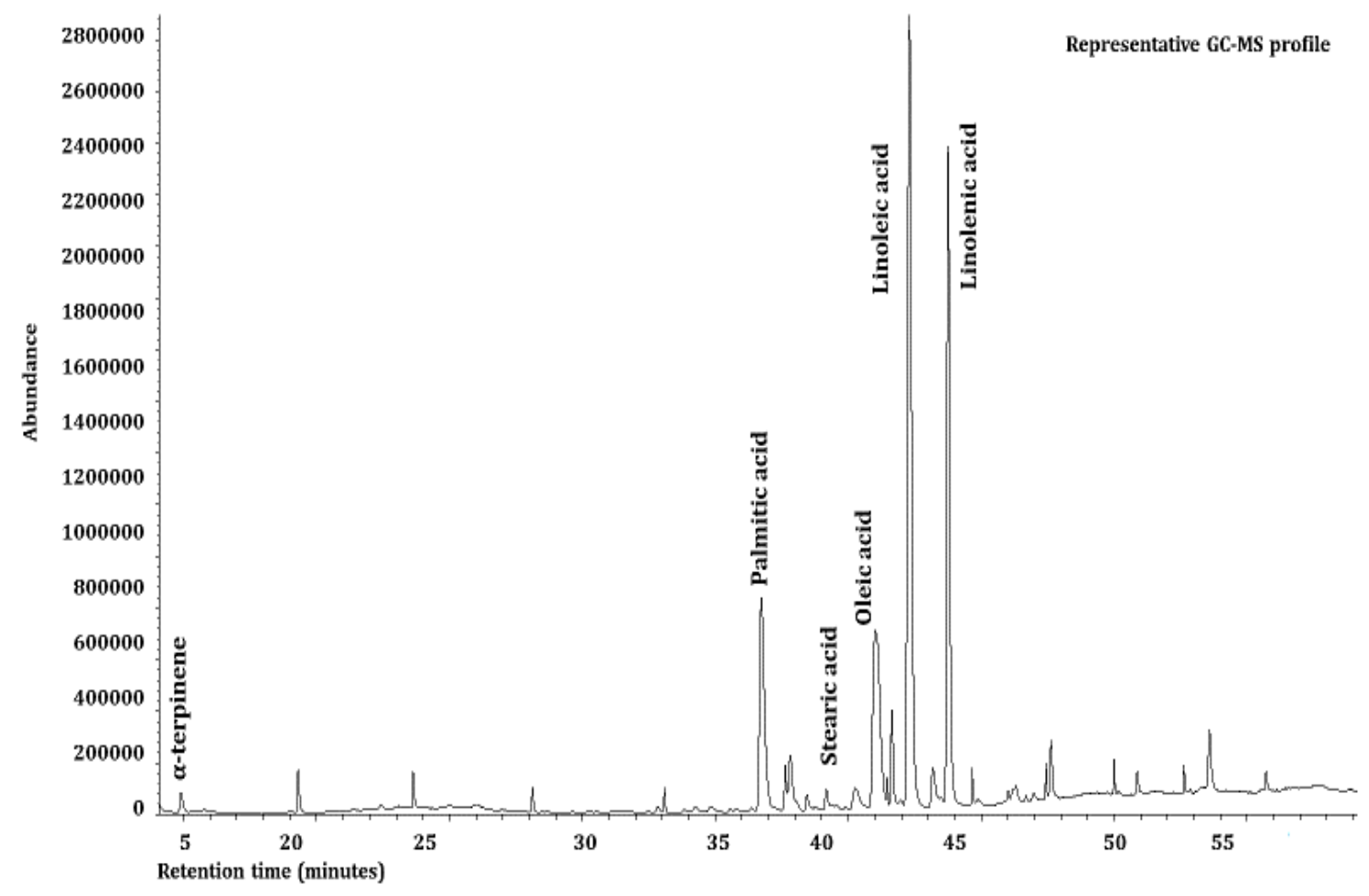

This study revealed that Xanthoria lichens exhibited high oxygen radical absorbance capacity, moderate radical scavenging and reducing capacities, moderate $\mathrm{AChE}$ and $\mathrm{BChE}$ and pronounced pancreatic lipase and high tyrosinase inhibitory activities. Since parietin compound primarily contributed of the total phenolics $(\geq 90 \%)$ and well correlated (a range of $r^{2}=0.8$ 0.98 ) with abovementioned antioxidant and enzyme inhibitory activities, it can be speculated that parietin might be the major contributor compound of biological activities of Xanthoria lichens with additive effects of volatile and fatty acid compounds. Therefore, bioactive rich Xanthoria lichens might be useful in the treatment and/or management of metabolic and/or neurological diseases as natural biotherapeutics. Additionally, parietin can also be utilized in chemotaxonomic studies of Xanthoria species as key phenolic compound. 
Table 3. Bioactive composition of Xanthoria species.

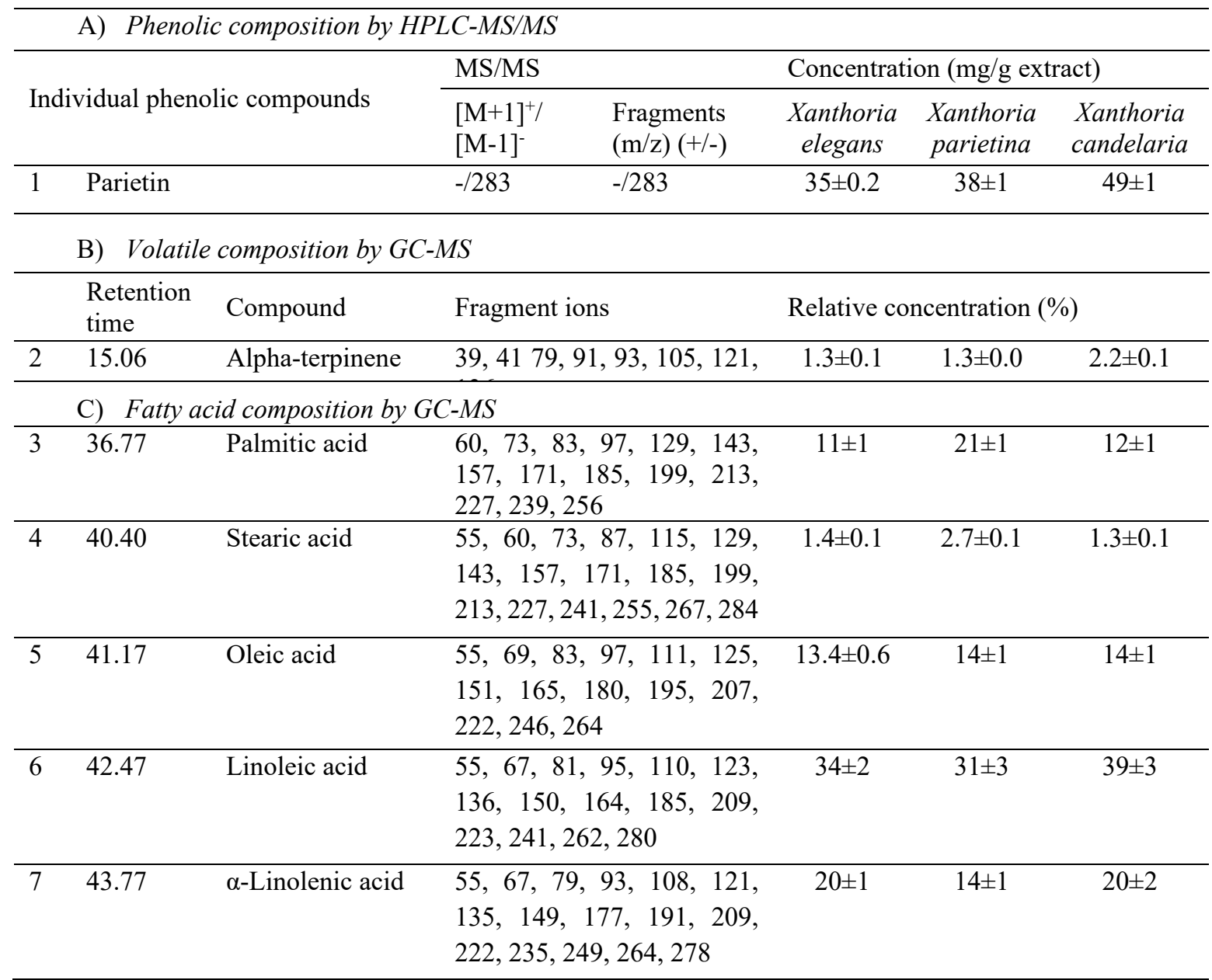

All data represent the mean \pm standard deviation of at least three independent experiments $(n=3)$.

\section{CONCLUSION}

This study reports the chemical profile, antioxidant and enzyme inhibitory activities Xanthoria lichens (X. parietina, X. elegans and X. candelaria) naturally grown and traditionally utilized as therapeutics in North Eastern Anatolia, Turkey. Parietin rich Xanthoria lichens exhibited pronounced antioxidant and enzyme inhibitory (particularly pancreatic lipase) activities. Xanthoria lichens might be novel candidates of biotherapeutics such as: Xanthoria candelaria for antioxidant and antilipase, Xanthoria elegans for anticholinesterase, and Xanthoria parietina for antiamylase and antiglucosidase activities. Data obtained within this study revealed that Xantoria species are belong to a high-tolerated lichen taxa towards to different ecological and climatic conditions due to their parietin content.

\section{Declaration of Conflicting Interests and Ethics}

The authors declare no conflict of interest. This research study complies with research and publishing ethics. The scientific and legal responsibility for manuscripts published in IJSM belongs to the authors.

\section{Authorship Contribution Statement}

Abdullah DALAR: Investigation, Methodology, Project administration, Visualization. Muzaffer MUKEMRE: Investigation, Methodology. Gokhan ZENGIN: Investigation, Methodology. Rabia Sena TURKER: Investigation, Methodology. Ali ASLAN: Funding acquisition, Investigation, Methodology, Project administration, Software, Visualization, Writing- original draft, Writing- review \& editing. 


\section{Orcid}

Abdullah DALAR (D) https://orcid.org/0000-0002-0080-2519

Muzaffer MUKEMRE (iD https://orcid.org/0000-0001-6154-6603

Gokhan ZENGIN (D) https://orcid.org/0000-0002-8901-6484

Rabia Sena TURKER iD https://orcid.org/0000-0002-2017-7159

Ali ASLAN (D) https://orcid.org/0000-0002-5122-6646

\section{REFERENCES}

Ainsworth, E.A., \& Gillespie, K.M. (2007). Estimation of total phenolic content and other oxidation substrates in plant tissues using Folin-Ciocalteu reagent. Nature Protocols, 2(4), 875-877.

Ali, S., \& Hameed, H.N. (2019). Antibacterial and antioxidant activity of a chemically induced mutant of Xanthoria parietina. The Journal of Animal and Plant Sciences, 29(3), 881-888.

Atalay, F., Halici, M.B., Mavi, A., Çakır, A., Odabasioglu, F., Kazaz, C., Aslan, A., \& Kufrevioglu, Ö.İ. (2011). Antioxidant phenolics from Lobaria pulmonaria L. Hoffm. and Usnea longissima Ach. lichen species. Turkish Journal Chemistry, 35, 647-661.

Basile, A., Rigano, D., Loppi, S., Santi, A.D., Nebbioso, A., Sorbo, S., Conte, B., Paoli, L., Ruberto, F.D., Molinari, A.M., Altucci, L., \& Bontempo, P. (2015). Antiproliferative, antibacterial and antifungal activity of the lichen Xanthoria parietina and its secondary metabolite parietin. International Journal of Molecular Sciences, 16, 7861-7875.

Benzie, I.F.F., \& Strain, J.J. (1996). The ferric reducing ability of plasma (FRAP) as a measure of "antioxidant power": the FRAP assay. Analytical Biochemistry, 239, 70-76.

Boustie, J., \& Grube, M. (2005). Lichens - a promising source of bioactive secondary metabolites. Plant Genetic Resources, 3(2), 273-287.

Bown, D. (2001). Encyclopedia of Herbs and Their Uses, second ed. Dorling Kindersley.

Calcott, M.J., Ackerley, D.F., Knight, A., Keyzers, R.A., \& Owen, J.G. (2018). Secondary metabolism in the lichen symbiosis. Chemical Society Reviews, 47(5), 1730-1760.

Chevallier, A. (1996). The Encyclopaedia of Medicinal Plants, first ed. Dorling Kindersley, London.

Copeland, R. A. (2000). Enzymes: A practical Introductions to Structure, Mechanism and Data Analysis, 2nd ed. Wiley.

Cornejo, A., Salgado, F., Caballero, J., Vargas, R., Simirgiotis, M., \& Areche, C. (2016). Secondary metabolites in Ramalina terebrata detected by UHPLC/ESI/MS/MS and identification of parietin as tau protein inhibitor. International Journal of Molecular Sciences, 17(8), 1303.

Dalar, A., \& Konczak, I. (2013). Phenolic contents, antioxidant capacities and inhibitory activities against key metabolic syndrome relevant enzymes of herbal teas from Eastern Anatolia. Industrial Crops and Products, 44, 383-390.

Fernandez-Moriano C., Gomez-Serranillos M.P., \& Crespo, A. (2016). Antioxidant potential of lichen species and their secondary metabolites. A systematic review. Pharmaceutical Biology, 54(1), 1-17.

Gonçalves, S., \& Romano, A. (2017). Inhibitory properties of phenolic compounds against enzymes linked with human diseases in: Soto-Hernandez, M., Palma-Tenango, M., GarciaMateos, M.R. (Eds.), Phenolic Compounds - Biological Activity. IntechOpen, Ltd., London, pp. 99-118.

Gundogdu, G., Gundogdu, K., Nalci, K.A., Demirkaya, A.K., Tasc1, S.Y., Miloglu, F.D., Senol, O., \& Hacimuftuoglu, A. (2019). The effect of parietin isolated from Rheum ribes L. on in vitro wound model using human dermal fibroblast cells. The International Journal of Lower Extremity Wounds, 18(1), 56-64. 
Hawksworth, D.L. (2003). Hallucinogenic and toxic lichens. International Lichenological Newsletter, 36, 33-35.

Ingólfsdóttir, K. (2002). Usnic acid. Phytochemistry, 61, 729-736.

Karthikaidevi, G., Thirumaran, G., Manivannan, K., Anantharaman, P., Kathiresan, K., \& Balasubaramanian, T. (2011). Antimicrobial activities of the lichen Roccella belangeriana (Awasthi) from mangroves of Gulf of Mannar. Indian Journal of Geo-Marine Sciences, 40(3), 449-453.

Kekuda, T. P., Lavanya, D., \& Pooja, R. (2019). Lichens as promising resources of enzyme inhibitors: A review. Journal of Drug Delivery and Therapeutics, 9(2), 665-676.

Kumar, J., Dhar, P., Tayade, A.B., Gupta, D., Chaurasia, O.P., Upreti, D.K., Arora, R., \& Srivastava, R.B. (2014). Antioxidant capacities, phenolic profile and cytotoxic effects of Saxicolous lichens from Trans-Himalayan cold desert of Ladakh. Plos One, 9(6), e98696.

Lina, A., Ghassan, K., Mohammed, W., \& Ahmed, E. (2015). Efficacy of extracts of some lichens for potential antibacterial activity. Research Journal of Pharmaceutical, Biological and Chemical Sciences, 6(1), 318-331.

Lopez-Tobar, E., Verebova, V., Blascakova, L., Jancura, D., Fabriciova, G., Sanchez-\& Cortes, S. (2016). Detection and aggregation of the antitumoral drug parietin in ethanol/water mixture and on plasmonic metal nanoparticles studied by surface-enhanced optical spectroscopy: Effect of $\mathrm{pH}$ and ethanol concentration. Spectrochimica Acta Part A: Molecular and Biomolecular Spectroscopy, 159, 134-140.

Manojlovic, N.T., Vasiljevic, P.J., Maskovic, P.Z., Juskovic, M., \& Bogdanovic-Dusanovic, G. (2012). Chemical composition, antioxidant, and antimicrobial activities of lichen Umbilicaria cylindrica (L.) Delise (Umbilicariaceae). Evidence-Based Complementary and Alternative Medicine, 452431.

Moldovan, L., Moldovan, N.I., 2004. Oxygen free radicals and redox biology of organelles. Histochemistry and Cell Biology, 122, 395-412.

Nybakken, L., Solhaug, K.A., Bilger, W., \& Gauslaa, Y. (2004). The lichens Xantoria elegans and Cetraria islandica maintain a high protection against UV-B radiation in arctic habitats. Oecologia, 140, 211-216.

Piervittori, R., Alessio, F., \& Maffei, M. (1994). Fatty acid variations in the lichen, Xanthoria parietina. Phytochemistry, 36(4), 853-856.

Pirie, A., Parsons, D., Renggli, J., Narkowicz, C., Jacobson, G.A., \& Shabala, S. (2013). Modulation of flavonoid and tannin production of Carpobrotus rossi by environmental conditions. Environmental and Experimental Botany, 87, 19-31.

Prior, R.L. (2015). Oxygen radical absorbance capacity (ORAC): New horizons in relating dietary antioxidants/bioactives and health benefits. Journal of Functional Foods, 18, 797810.

Raj, P.S., Prathapan, A., Sebastian, J., Antony, A.K., Riya, M.P., Rani, M.R.P., Biju, H., Priya, S., \& Raghu, K.G. (2014). Parmotrema tinctorum exhibits antioxidant, antiglycation and inhibitory activities against aldose reductase and carbohydrate digestive enzymes: an in vitro study. Natural Product Research, 28(18), 1480-1484.

Reddy, V.M., O’Sullivan, J.F., \& Gangadharam, PR. (1999). Antimycobacterial activities of riminophenazines. Journal of Antimicrobial Chemotherapy, 43, 615-623.

Torres, A., Dor, I., Rotem, J., Srebnik, M., \& Dembitsky, V.M. (2003). Characterization of surface n-alkanes and fatty acids of the epiphytic lichen Xanthoria parietina, its photobiont a green alga Trebouxia sp., and its mycobiont, from the Jerusalem hills. European Journal of Biochemistry, 270(10), 2120-2125.

Shivanna, R., Hengameh, P., \& Rajkumar, H.G. (2015). Screening of lichen extracts for in-vitro antidiabetic activity using alpha-amylase inhibitory assay. International Journal of Biological \& Pharmaceutical Research, 6(5), 364-367. 
Uysal, S., Zengin, G., Locatelli, M., Bahadori, M.B., Mocan, A., Bellagamba, G., \& Aktumsek, A. (2017). Cytotoxic and enzyme inhibitory potential of two Potentilla species (P. speciosa L. and P. reptans Willd.) and their chemical composition. Frontiers in Pharmacology, 23(8), 290.

Uzun, Y., Dalar, A., \& Konczak, I. (2017). Sempervivum davisii: phytochemical composition, antioxidant and lipase-inhibitory activities. Pharmaceutical Biology, 55, 532-540.

Valadbeigi, T., \& Shaddel, M. (2016). Amylase inhibitory activity of some macro lichens in Mazandaran province, Iran. Physiology and Pharmacology, 20, 215-219.

Zambare, V.P., \& Christopher, L.P. (2012). Biopharmaceutical potential of lichens. Pharmaceutical Biology, 50(6), 778-798.

Zengin, G. (2016). A study on in vitro enzyme inhibitory properties of Asphodeline anatolica: new sources of natural inhibitors for public health problems. Industrial Crops and Products, $83,39-43$. 